\title{
Guns, Butter, and Openness: On the Relationship Between Security and Trade
}

\author{
By Stergios Skaperdas and Constantinos Syropoulos*
}

Sovereign states arm to defend real or hypothetical interests, presumably because they cannot engage in complete, long-term contracting that would prevent such arming. International trade, therefore, takes place within an essentially anarchic context, and we can expect trade regimes and security policies to be related. Indeed, many embargoes, sanctions, and various other forms of trade restrictions that have been used throughout history and continue to be used today can be considered extensions of security policies, whereas some security policies can be attributed to trade policy.

The relationship between trade and security, however, has been barely explored within economics. ${ }^{1}$ We could fairly characterize the prevailing view within the discipline as the classical liberal view, according to which the expansion of international trade does not just increase the welfare of the trading partners, but can also patch up any differences they might have over other contentious issues. (Solomon Polachek [1980] represents a rare articulation of this widely held perspective.) More boldly, it could be argued that the expansion of trade

\footnotetext{
* Skaperdas: Department of Economics, University of California, Irvine, CA 92612; Syropoulos: Department of Economics, Florida International University, Miami, FL 33199. We thank Gary Richardson and Scott Taylor for very useful comments. Syropoulos thanks the FIU/Provost Foundation for a summer grant, and Skaperdas thanks the GPACS Center for financial support.

${ }^{1}$ Recent research that has considered aspects of the relationship between security and trade has analyzed Ricardian models in which international trade is insecure, either because of the presence of pirates and bandits (James Anderson and Douglas Marcouiller, 1997) or because the two sides influence the terms of trade through arming (Charles Anderton et al., 1999). Both of these papers show that autarky is an equilibrium for fairly large sets of parameters and therefore make the basic point that much international trade can be hampered by the anarchy that characterizes international relations. Models like that of Jack Hirshleifer (1988), suitably adapted, could also make the same point. In a different vein, Martin McGuire (2000) has examined the effects of supply uncertainties on trade policy.
}

always alleviates conflict by forcing the adoption of measures that manage conflict. Nevertheless, one does not need to dig much into history to show that, while trade and economic interdependence can contribute to the peaceful resolution of disputes, they are not sufficient by themselves to guarantee the absence of war and the reduction of arming. Many observers before World War I, for example, considered that the hitherto unprecedented expansion of trade and interdependence between Britain and Germany made war unthinkable and impossible, yet war occurred and with much ferocity and destruction. Furthermore, as Donald Kagan (1995 pp. 373-80) has argued, the British policy of appeasement toward Germany during the 1930's was based on similar arguments about the use of economic carrots to avoid war. What can interfere with peace and arms reduction when trade expands is what some political scientists have called the "security externality of trade" (Joanne Gowa, 1994). Trade changes the incentives for (and can increase) arming to an extent that its cost may outweigh the benefits of openness. Such effects are behind the view of the realist and neorealist schools of international relations, according to which countries may impose trade restrictions because of security considerations.

To begin discussing the classical liberal and realist views we analyze a simple model that allows for possible insecurity as well as trade. We examine an economic environment in which two "small" countries dispute a resource that can be used in the production of tradables. Claims on the resource are developed through arming. We analyze the effects of different trade regimes on arming and on the welfare of each country. In the model we consider, one effect we find is that trade, by equalizing the prices of traded goods, equalizes the marginal benefits and opportunity costs of arming for two interacting countries and thus "levels the playing field" for arming. Then, the incentives for arming can be very different in the presence of trade than under 
autarky. Further, if the international price of the contested resource is lower than a country's autarkic price, the opportunity cost of arming rises, and thus, the introduction of trade softens the intensity of competition for the contested resource, reduces arming, and raises welfare relative to autarky. The opposite can occur, however, when the international price of the contested resource is higher than its autarkic price. Thus, we find different conditions under which the liberal and realist views hold.

\section{Guns, Butter, and Oil}

Consider two countries, with each country $i=1,2$ possessing $T_{i}$ units of secure land and $L_{i}$ units of secure labor. Further, there are $T_{0}$ units of disputed land which the two countries contest. Land is valuable because it contains oil. For simplicity, we assume that one unit of land translates into one unit of oil, whereas labor can be used to produce one-toone guns or butter. Then, letting $G_{i}$ denote the quantity of guns under country $i$ 's control, the maximal production of butter in country $i$ is $\max \left\{0, L_{i}-G_{i}\right\}$.

Oil and butter are final goods, and consumer preferences take the Cobb-Douglas form,

$$
\begin{aligned}
U_{i}\left(O_{i}, B_{i}\right) & =O_{i}^{\alpha} B_{i}^{\beta} \\
\alpha & +\beta=1 \quad \alpha \in(0,1)
\end{aligned}
$$

where $O_{i}$ and $B_{i}$ are the aggregate quantities of oil and butter consumed in country $i=1,2$.

For a country to develop a claim on the disputed land $T_{0}$ (and, consequently, on the associated quantity of oil $T_{0}$ ), it has to arm. Since the other country, which becomes de facto its adversary, may also arm, the two countries' claims on $T_{0}$ depend on their relative amounts of arming. We assume that country $i$ 's $(=1,2)$ share of $T_{0}$ is given by

$$
\phi_{i}=\frac{G_{i}^{m}}{G_{1}^{m}+G_{2}^{m}} \quad \text { for } m \leq 1
$$

Let $p_{i}$ denote the relative price of butter in country $i$ measured in units of oil. Under our production structure, $p_{i}$ also represents the relative price of labor and the opportunity cost of guns. Thus, given guns, the value of country $i$ 's gross domestic product (GDP) or revenue is

$$
\begin{aligned}
& R_{i}=T_{i}+\phi_{i} T_{0}+p_{i}\left(L_{i}-G_{i}\right) \\
& i=1,2 .
\end{aligned}
$$

Solving the consumer's problem of maximizing the utility function in (1) subject to the budget constraint that the country's aggregate expenditure is equal to the value of its GDP in (3) generates the indirect utility function

$$
V_{i}=\Gamma p_{i}^{-\beta} R_{i}
$$

where

$$
\Gamma \equiv \alpha^{\alpha} \beta^{\beta} \quad \text { for } i=1,2
$$

which is clearly a function of the two countries' guns, the relative price of butter, its secure factor endowments and the contested land.

Henceforth, we suppose that policymakers in the two countries determine national security policy (i.e., how many guns to produce) so as to maximize welfare $V_{i}$ in (4). There are two potential channels through which guns have an effect. The first channel is the country's GDP. Ceteris paribus, a larger $G_{i}$ raises the country's income $R_{i}$ because it increases the country's share of the contested oil $T_{0}$. However, an increase in guns also causes the country's GDP to fall because less labor is used for the production of butter. The second channel through which the effect of guns may travel is the relative price of butter. Exactly how this price may be affected depends on the regime one considers.

In what follows, we explore the implications for arming and welfare under the following two regimes: (i) autarky, in which the two countries divide the contested land (oil) according to the relative amounts of guns, and then each country consumes the oil and butter it produces domestically; and (ii) trade, whereby the contested land is divided according to the relative amounts of guns, and then oil is traded for butter in international markets. In the former case, the domestic market-clearing relative price of butter is determined endogenously as a function of 
guns. In the latter case, the world price $p$ of butter is exogenously given, as both countries are considered to be "small."

\section{A. Autarky}

Let superscript A identify variables under autarky. For given guns, the market-clearing relative price of butter and labor in country $i$ then becomes:

$$
p_{i}^{\mathrm{A}}=\left(\frac{\beta}{\alpha}\right)\left(\frac{T_{i}+\phi_{i} T_{0}}{L_{i}-G_{i}}\right) \quad i=1,2
$$

An increase in country $i$ 's gun production causes this price to rise because it raises the domestic supply of oil and reduces the supply of butter.

Turning to welfare, an explicit expression can be obtained by substituting (5) into (4). That is, each country's welfare can be written as a function of its security-policy strategy, guns. (It is straightforward to establish existence and uniqueness of Nash equilibrium under general conditions.) It can be shown that when the countries are different their equilibrium choices of guns will differ. However, for specificity, here we consider the case with identical countries, in which we have

$$
G_{i}^{\mathrm{A}}=\frac{\frac{m}{4}}{\frac{m}{4}+\left(\frac{\beta}{\alpha}\right)\left(\frac{1}{2}+\tau\right)} L \quad i=1,2
$$

where $L_{i}=L, T_{i}=T$, and $\tau \equiv T / T_{0}$ (the latter is a measure of security in land) $\forall i=1,2$. As can be seen from (6), the equilibrium quantity of guns is increasing in the amount of labor $L$ each country owns and in the effectiveness of conflict parameter $m$, but decreasing in the degree of land security $\tau$ and in the relative importance $\beta / \alpha$ of butter in consumption. Substituting (6) into (5) and (4) yields the following expression for the Nash equilibrium price under autarky:

$$
\begin{aligned}
\tilde{p}_{i}^{\mathrm{A}} & =p_{i}^{\mathrm{A}}\left(G_{1}^{\mathrm{A}}, G_{2}^{\mathrm{A}}\right) \\
& =\frac{T_{0}}{L}\left[\frac{m}{4}+\left(\frac{\beta}{\alpha}\right)\left(\frac{1}{2}+\tau\right)\right] .
\end{aligned}
$$

How $\tilde{p}_{i}^{\text {A }}$ depends on the various parameters can be easily derived. We can similarly derive the equilibrium welfare under autarky, which we denote by $\tilde{V}_{i}^{\mathrm{A}}$. (For this and other expressions, as well as additional derivations, an expanded version of this paper is available from either author upon request.)

\section{B. Opening Up to Trade}

Consider now the possibility of both countries participating in the world market where oil and butter are traded freely at a relative price $p$ for butter. The countries will treat this price as a parameter because they are "small." It follows that country i's payoff function under trade $V_{i}^{\mathrm{F}}$ can be obtained from (4) by replacing $p_{i}$ with $p$. Because now both countries face the same price, $p$, of butter as well as of labor, the opportunity cost of guns for each country is constant and does not differ across these countries. When the labor constraint is not binding for either economy, we obtain the following Nash equilibrium choice of guns:

$$
G_{i}^{\mathrm{F}}=\frac{m}{4 p} T_{0} \quad i=1,2 .
$$

Because the two countries face identical opportunity costs of arming, opening up to free trade levels the playing field and induces both countries to produce identical quantities of guns. In addition, and contrary to the case under autarky described in (6), equilibrium arming does not depend on the countries' initial labor endowments, on their secure land endowments, or on consumer tastes. It thus appears that arming under autarky and arming under trade are hardly related, and therefore the possibility exists that

\footnotetext{
2 In related work, we have allowed for "large" countries. In Skaperdas and Syropoulos (1996) we have examined the possibility of war over land (instead of its division) and shown how under a limited set of conditions it can be preferred to unrestricted trade. In Skaperdas and Syropoulos (2000), we show that the terms of trade are determined by bargaining and that trade is Pareto superior to autarky only when the players are sufficiently different from one another.
} 
trade may bring about much lower or much higher arming than autarky for either country.

The equilibrium welfare for each country, denoted by $\tilde{V}_{i}^{\mathrm{F}}(p)$, can be easily derived and can be shown to be a convex function of $p$ with a minimum at a certain price $p_{i}^{\min }$. When guns are fixed, welfare is minimized at the autarkic price $p_{i}^{\mathrm{A}}$. Yet, with endogenously determined guns and under conditions of symmetry, $p_{i}^{\text {min }}<$ $\tilde{p}_{i}^{\mathrm{A}}$ and $\tilde{V}_{i}^{\mathrm{F}}\left(\tilde{p}_{i}^{\mathrm{A}}\right)=\tilde{V}_{i}^{\mathrm{A}}$. Furthermore, there exists a $\tilde{p}_{i}\left(<p_{i}^{\min }\right)$ such that $\tilde{V}_{i}^{\mathrm{F}}\left(\tilde{p}_{i}\right)=\tilde{V}_{i}^{\mathrm{A}}$. For the remainder of the paper we focus on the case of identical countries, which implies $\tilde{p}_{1}^{\mathrm{A}}=\tilde{p}_{2}^{\mathrm{A}}=$ $\tilde{p}^{\mathrm{A}}$, and whenever there is no risk of confusion we drop the subscript $i$.

\section{Comparing Trade and Autarky}

From the properties we have just stated, it follows that

$$
\begin{array}{r}
\tilde{V}^{\mathrm{F}}(p) \leq \tilde{V}^{\mathrm{A}} \quad \text { if and only if } p \in\left[\tilde{p}, \tilde{p}^{\mathrm{A}}\right] \\
i=1,2 .
\end{array}
$$

In words, autarky is superior to unrestricted trade when the world price $p$ of butter lies in the range $\left(\tilde{p}, \tilde{p}^{\mathrm{A}}\right)$. For prices outside this range, each country prefers free trade. When the world price of butter exceeds its autarkic level, butter (oil) becomes more (less) valuable, and thus the opportunity cost of guns rises. The countries then choose to devote less labor to arming and more to butter which they export in return for oil imports. Trade in this case does not just bring its ordinary gains, but also the extra benefit of reduced arming. However, when the world price of butter is below its autarkic price, the incentives are in the opposite direction. They lead to more arming and less production of butter which is imported in return for the domestically produced oil. In such conditions, trade has such a negative security externality that outweighs the gains from trade. At low enough world prices of butter, all labor is devoted to arming [so that (8) is no longer the equilibrium choice]. Further reductions in $p$ no longer increase arming, but they increase the butter that can be obtained internationally through the export of the more valuable oil. For prices below $\tilde{p}$ the gains from trade outweigh the negative security externality, and free trade brings higher welfare than autarky.

To see the intuition behind the above ideas more clearly, we consider unrestricted trade with endogenously determined guns more closely. Differentiation of country $i$ 's indirect utility with respect to $p$ and utilization of the envelope theorem yields

$$
\begin{aligned}
& d V_{i}^{\mathrm{F}} / d p \\
& =\Gamma p^{-\beta}\left[-M_{i}^{\mathrm{F}}+T_{0} \frac{\partial \phi_{i}}{\partial G_{j}}\left(d G_{j}^{\mathrm{F}} / d p\right)\right] \\
& \quad i \neq j=1,2
\end{aligned}
$$

where $M_{i}^{\mathrm{F}}=\beta R_{i}^{\mathrm{F}} / p-\left(L_{i}-G_{i}^{\mathrm{F}}\right)$ is the excess demand for butter in country $i$ and is obtained from Roy's identity and the fact that $\partial R_{i} / \partial p_{i}=$ $L_{i}-G_{i}$. The first term inside the square brackets captures the direct welfare effect of world price changes; it is negative if country $i$ imports butter and positive if it exports it. The second expression is a strategic effect and is related to the security externality discussed earlier. As can be ascertained from (2) and (8), we have $\partial \phi_{i} / \partial G_{j}<0(i \neq j=1,2)$ and $d G_{j}^{\mathrm{F}} / d p<0$; therefore, this externality is positive (negative) when the world price $p$ rises (falls) because the opportunity cost of guns in country $j$, country $i$ 's adversary, rises (falls).

Now suppose $p=\tilde{p}^{\mathrm{A}}$ initially, which implies $\tilde{V}^{\mathrm{F}}(p)=\tilde{V}^{\mathrm{A}}$ and $\tilde{M}_{i}^{\mathrm{F}}=0$, and consider a change in the world price $p$ of butter. Since, as indicated in (10), now only the security externality matters, country i's welfare unambiguously rises (falls) above (below) its autarky level as $p$ increases (falls) because its adversary produces less (more) guns. If the price $p$ rises continuously above the $\tilde{p}^{\mathrm{A}}$ level, country $i$ becomes an exporter of butter, and thus trade is unambiguously welfare-improving. In contrast, when $p$ falls below $\tilde{p}^{\mathrm{A}}$, country $i$ becomes an importer of butter, and thus the initial fall in welfare is tempered by the improvement in its terms of trade. Eventually, when the price $p$ falls considerably, this beneficial terms-of-trade effect outweighs the adverse security effect, and once again, trade becomes beneficial. In fact, when this price falls below a certain level, only the beneficial terms-of-trade effect will be 
present, because country $j$ will specialize in the production of guns, and the negative security externality will disappear. This suggests the existence of a $\tilde{p}$ such that $\tilde{V}^{\mathrm{F}}(\tilde{p})=\tilde{V}^{\mathrm{A}}$, as claimed earlier.

We emphasize that the possibility of welfarereducing trade arises here solely because of a negative security externality. It is a well-known proposition in international-trade theory that, when property is completely secure, domestic distortions are absent, and a country is small in world markets, unrestricted trade cannot be inferior to autarky; the optimal policy for such a country is unrestricted trade. However, when some property is insecure, the possibility arises that trade intervention will be welfareimproving if it induces a country's adversary to produce a smaller quantity of guns. This can be shown to require precommitment: trade policy should be implemented prior to the determination of the interacting countries' security policies. Finally, we mention in passing that the insights of this paper can also prove helpful in shedding light on another question: how the presence of insecure property affects trade patterns, as compared to the world of secure property considered in neoclassical trade theory.

\section{Concluding Remarks}

The expansion of trade and economic interdependence over the past 50 years, coupled with the absence of major wars, might give the impression that humanity has now crossed a threshold which relegates insecurity and its possible effects on openness to the dustbin of history. That might eventually turn out to be true, but in the meantime, insecurity and contention among states are alive in many parts of the world. From the Spratly Islands in the South China sea that seven countries contest, to Kashmir, Central Asia, the Caucasus, the Middle East, or the Congo, countries expend a significant percentage of their national incomes on arming. The resultant insecurity and arming do not just subtract from their welfare directly, but also, as we have shown, can have significant indirect effects through the trade posture that the affected countries adopt.

Solving the problem of insecurity entails the development of commitment devices that would reduce or eliminate the need to arm. Such com- mitment devices, however, are not easy to come by, and they take a long time to develop. Europe is a good example of that. After the experience of the two world wars, the original six members of the European Community slowly began to develop mechanisms of economic integration that were in large part institutions of conflict management as well. That coupled process of integration and conflict resolution through bureaucratic and political struggle, instead of through the battlefield, is ongoing and far from complete after a century of tribulations. Trade and economic interdependence can help resolve conflict, but it is naive and scientifically inappropriate to think that they are sufficient by themselves to do so.

\section{REFERENCES}

Anderson, James E. and Marcouiller, Douglas. "Trade and Security I: Anarchy." Unpublished manuscript, Boston College, October 1997.

Anderton, Charles; Anderton, Roxanne and Carter, John R. "Economic Activity in the Shadow of Conflict." Economic Inquiry, January 1999, 37(1), pp. 166-79.

Gowa, Joanne. Allies, adversaries, and international trade. Princeton, NJ: Princeton University Press, 1994.

Hirshleifer, Jack. "The Analytics of Continuing Conflict." Synthese, August 1988, 76(2), pp. 201-33.

Kagan, Donald. On the origins of war. New York: Doubleday, 1995.

McGuire, Martin. "Provision for Adversity." Journal of Conflict Resolution, December 2000, 44(6), pp. 730-52.

Polachek, Solomon W. "Conflict and Trade." Journal of Conflict Resolution, March 1980, 24(1), pp. 55-78.

Skaperdas, Stergios and Syropoulos, Constantinos. "Competitive Trade With Conflict," in M. R. Garfinkel and S. Skaperdas, eds., The political economy of conflict and appropriation. New York: Cambridge University Press, 1996, pp. 73-95.

. "Insecure Property and the Efficiency of Exchange." Unpublished manuscript, University of California-Irvine, May 2000; Economic Journal (forthcoming). 